RESEARCH ARTICLE

https://doi.org/10.17059/ekon.reg.2021-1-6

UDC 338.2

\author{
Ernest Baba Ali ${ }^{a)}$, Bismark Amfo ${ }^{\text {b) }}$ \\ a) Ural Federal University, Ekaterinburg, Russian Federation \\ b) University of Energy and Natural Resources, Ghana \\ a) http://orcid.org/0000-0001-7053-3492,e-mail: ernestali2014@gmail.com \\ b) https://orcid.org/0000-0002-5009-2033
}

\title{
Comparing the values of economic, ecological and population indicators in High- and Low-Income Economies
}

The quest to achieve economic development worldwide has increased carbon dioxide $\left(\mathrm{CO}_{2}\right)$ emissions, which could vary in high- and low-income economies due to differences in economic activities. Using empirical evidence from the panel data for the period 1960-2018 obtained from the World Bank, we investigate differences in the impact of population, gross domestic product (GDP), and renewable energy on $\mathrm{CO}_{2}$ emissions in high- and low-income economies. For that purpose, we applied the Pesaran cross-sectional dependence test (for cross-sectional dependence), Levin-Lin-Chu unit root test (for Unit roots), Granger causality Wald test (for the possibility of Granger causality among the variables), fixed-effects and random-effects regressions. We established that population, GDP and energy consumption considerably influence $\mathrm{CO}_{2}$ emissions. Results of the Granger causality Wald test, fixed-effects and random-effects regressions clearly demonstrated that growth in population and GDP directly correlates with $\mathrm{CO}_{2}$ emissions in high-and low-income economies, while renewable energy consumption has an indirect correlation. While there are no differences in terms of directions, we revealed differences in the magnitude in high-and low-income economies. The impact of population and renewable energy consumption on $\mathrm{CO}_{2}$ emissions in low-income economies is greater than that of high-income economies. The impact of $\mathrm{GDP}$ on $\mathrm{CO}_{2}$ emissions is greater in high-income economies than in low-income economies. Thus, to reduce $\mathrm{CO}_{2}$ emissions, policy makers should promote low carbon emission economic activities and implement population control measures.

Keywords: population, gross domestic product, renewable energy, $\mathrm{CO}_{2}$ emission, high-income economies, low-income economies, Granger causality, random-effects regressions, fixed-effects regressions

For citation: Ali, E. B. \& Amfo, B. (2021). Comparing the values of economic, ecological and population indicators in High- and Low-Income Economies. Ekonomika regiona [Economy of region], 17(1), 72-85, https://doi.org/10.17059/ekon. reg.2021-1-6

1 () Ali E. B., Amfo B. Text. 2021. 


\author{
Э. Б. Али ${ }^{a)}$, Б. Амфо б) \\ ф) Уральский федеральный университет, Екатеринбург, Российская Федерация \\ 6) Университет энергетики и природных ресурсов, Гана \\ a) http://orcid.org/0000-0001-7053-3492, e-mail: ernestali2014@gmail.com \\ 6) https://orcid.org/0000-0002-5009-2033
}

\title{
Сравнение демографических, экономических и экологических показателей в странах с высоким и низким доходом
}

\begin{abstract}
Глобальное стремление к экономическому развитию привело к увеличению выбросов углекислого газа, объем которых различается в странах с высоким и низким уровнем дохода вследствие различной интенсивности. В настоящей статье на основе панельных данных за период с 1960 г. по 2018 г., опубликованных Всемирным банком, рассматривается взаимосвязь показателей населения, валового внутреннего продукта (ВВП) и возобновляемых источников энергии и выбросов $\mathrm{CO}_{2}$ в странах с высоким и низким уровнем доходов. Для достижения поставленной иели были использованы такие методы, как тест на кросс-зависимость Песарана, тест на единичный корень Левина - Лина- Чу, тест Вальда на причинность Грейнджера, регрессии с фиксированньми и случайными эффектами. Выявлено, что объем выбросов $\mathrm{CO}_{2}$ в значительной мере зависит от населения, объема ВВП и потребления энергии. Результаты теста Вальда на причинность Грейнджера, а также регрессии с фиксированными эффектами и случайными эффектами показали, что рост населения и ВВП напрямую влияет на выбросы СО в странах как с высоким, так и с низким доходом, тогда как влияние потребления возобновляемой энергии имеет косвенный характер. Несмотря на отсутствие различий в направлениях корреляиии, были выявлены различия в масштабах взаимосвязи в странах с высоким и низким уровнем доходов. Влияние населения и потребления возобновляемых источников энергии на выбросы $\mathrm{CO}_{2}$ в странах с низкими доходами больше, чем в странах с высокими доходами. Влияние ВВП на выбросы $\mathrm{CO}_{2}$ выше в странах с высоким уровнем доходов, нежели в странах с низким уровнем. Таким образом, чтобы сократить выбросы $\mathrm{CO}_{2}$, представителям власти следует принимать экономические и демографически меры для снижения уровня выбросов углерода.

Ключевые слова: население, валовой внутренний продукт, возобновляемые источники энергии, выбросы СО страны с высокими доходами, страны с низкими доходами, причинность по Грейнджеру, регрессии со случайными эффектами, регрессии с фиксированными эффектами
\end{abstract}

Для цитирования: Али Э. Б., Амфо, Б. Сравнение демографических, экономических и экологических показателей в странах с высоким и низким доходом // Экономика региона. 2021. Т. 17, вып. 1. С. 72-85. https://doi.org/10.17059/ ekon.reg.2021-1-6

\section{Introduction}

The quest to achieve economic development worldwide to meet the demands of the constantly growing population has led to an increase in the demand for energy [1]. Consequently, the world is witnessing a rise in air emissions, especially carbon dioxide $\left(\mathrm{CO}_{2}\right)$. Human-related $\mathrm{CO}_{2}$ emissions, which alter natural processes occurring in the atmosphere, are, therefore, responsible for the emergence of global warming [2]. Even though efforts are being made to cut down emissions by signing agreements such as the Kyoto Protocol and the Paris Agreement at the global level, emissions by countries continue to rise. Developing countries have been mainly responsible for much of the increase in $\mathrm{CO}_{2}$ emissions; moreover, it is predicted that this trend will continue in the coming decades [3]. For instance, in 2016 alone, China emitted 10.7 billion tonnes of $\mathrm{CO}_{2}$ emissions, including emissions from coal that amounted to $34 \%$ [4]. Highly populated countries like China have serious issues with energy security and, hence, have a negative impact on the greenhouse effect. Therefore, it is necessary to take drastic measures to reduce emissions in the immediate future since greenhouse gases remain in the atmosphere for a very long time no matter how soon emissions are stopped [2].

While the energy consumption is usually linked to high consumption of fossil fuels, the use of sustainable renewable energy sources to meet energy demand is slowly gaining momentum [5, 6, 7]. For example, the European Union in the Europe 2020 strategy set a target to ensure a decrease in energy demand per unit of gross domestic product $(G D P)$ in the economy by increasing energy efficiency [6].

Increasing cost of energy coupled with global strategies aimed at environmental pollution reduction has resulted in a number of studies on the nexus between $G D P$, population, renewable energy, and $\mathrm{CO}_{2}$ emissions. Countries relying on energy consumption could face a trade-off between implementing strategies to reduce environmental pollution while increasing energy efficiency and strategies to stimulate economic growth [6]. Given that the industrial sector is more energy-intensive than the service sector, the former achieves eco- 
nomic growth by increasing energy consumption, leading to energy inefficiency. In this regard, it is highly probable that the most developed countries with fewer industries will be more energy-efficient compared to developing countries [6].

Using empirical evidence from balanced panel data for the period from 1960 to 2018, we established and compared the nexus between population size, GDP growth, renewable energy, and $\mathrm{CO}_{2}$ emissions for developed and developing economies. The study answers the question: do population size, GDP growth, and renewable energy have a different impact on $\mathrm{CO}_{2}$ emissions in developed and developing economies? Thus, we tested the following research hypotheses:

1. Population size, GDP growth, renewable energy, and $\mathrm{CO}_{2}$ emissions are causally related, meaning that they influence one another.

2. There are differences in the nexus between population, $G D P$, renewable energy, and $\mathrm{CO}_{2}$ in high- and low-income economies.

3. There are differences in the influence of population size, GDP growth, and renewable energy on $\mathrm{CO}_{2}$ emissions in high- and low-income economies.

It is imperative that high-income countries have greater economic activities and technological advancements compared to low-income countries. Economic activities boost a country's GDP but increase $\mathrm{CO}_{2}$ emissions. Alternatively, technological advancements could reduce $\mathrm{CO}_{2}$ emissions, and simultaneously increase renewable energy utilisation. Technological advancements could also boost income generating activities, and, thus, $G D P$. Therefore, it is unclear whether the relationships between population, $G D P$, renewable energy, and $\mathrm{CO}_{2}$ emissions in high- and low-income economies would be similar. Given this background, research findings help analyse potential discrepancies and similarities in the nexus between these four variables in high- and low-income economies. This will help governments and policy-makers in these two groups of economies to formulate and design policies and strategies specific to their economic and developmental situations. Furthermore, increase in a country's population leads to a potential increase in its labour force and human capital. These changes enhance economic activities in the country, which could hypothetically results in GDP growth. Nevertheless, if such economic activities are not environmentally friendly, they can increase $\mathrm{CO}_{2}$ emissions. A possible means of reducing $\mathrm{CO}_{2}$ emissions is the development of technologies that increase renewable energy utilisation in a country. Therefore, it is important to understand the causal association between population size, GDP growth, renewable energy, and $\mathrm{CO}_{2}$ emissions.

The paper is organised as follows. The second section presents the empirical literature on relevant problems. The third section discusses the materials and methods. The fourth section reports on the empirical findings. The final section includes conclusions and policy recommendations.

\section{Existing Studies on the Nexus between Population, GDP, Renewable Energy, and $\mathrm{CO}_{2}$ Emissions}

A considerable number of studies have explored the links between $\mathrm{CO}_{2}$ emissions and GDP while considering population and energy consumption to illustrate the interactions that exist between these indicators [8-12]. Kang et al. [13] assessed the nexus between $\mathrm{CO}_{2}$ emissions, renewable and non-renewable energy resources, and economic growth based on quarterly data from 1965 to 2015 . Using panel data from 69 countries, Liu and Hao [14] examined the relationship between energy consumption and economic growth for the period from 1970 to 2013. By using the vector correction model, the fully modified ordinary least square $(O L S)$, and the dynamic OLS (DOLS), they found a long-run two-way relationship between the variables as well as a long-run growth in due to renewable energy consumption for energy-importing countries.

Nathaniel \& Iheonu [15] examined the role of renewable and non-renewable energy consumption in Africa using the Augmented Mean group estimation technique analysing a dataset for the period from 1990 to 2014. They found a negative relationship between renewable energy and $\mathrm{CO}_{2}$ emissions in Africa while non-renewable energy positively influenced $\mathrm{CO}_{2}$ emissions. However, the researchers observed that the degree of influence of the two sources of energy varied across countries with a unidirectional causality from both energy sources to $\mathrm{CO}_{2}$ emissions. Salman et. al. [16] also employed the fully modified OLS and the dynamic OLS to estimate the nexus between growth and emissions in Indonesia, South Korea, and Thailand over the period from 1990 to 2016. They observed a one-way causality running from $\mathrm{CO}_{2}$ emissions to economic growth and energy use to $\mathrm{CO}_{2}$ emissions, both in the short and long term.

Although a number of studies examined population, GDP, renewable energy, and $\mathrm{CO}_{2}$ emissions, it is difficult to find a research that considers the causal interaction between all four variables. In addition, majority of previous studies on these variables focused on specific countries, sub-regions, developed or developing countries. 
Therefore, despite discrepancies in economic activities and technological advancements, it is difficult to find a study that compares the causal relationship between population, $G D P$, renewable energy, and $\mathrm{CO}_{2}$ emissions in high- and low-income economies. To bridge this research gap, we assessed and compared similarities and differences in the nexus between population, GDP, renewable energy, and $\mathrm{CO}_{2}$ emissions in high- and low-income economies.

\section{Materials and Methods}

\subsection{Data}

We used the panel dataset from the World Bank covering high-, low- and middle-income economies in the period from 1960 to 2018. As a result, the panel variable is countries categorised as high-, low- and middle-income economies. The time variable is years, 1960 to 2018. For the study, we adopted the World Bank definition and classification of countries in the world to distinguish high-, low- and middle-income economies. Based on the World Bank country classification, high-income economies are countries with gross national income $(G N I)$ per capita of US $\$ 12,376$ or more in 2018. Low-income economies are those with a GNI per capita of US $\$ 1,025$ or less in 2018. Lower middle-income economies are countries with a GNI per capita between US\$1,026 and US\$3,995 in 2018. Upper middle-income economies are countries with a GNI per capita between US\$3,996 and US\$12,375 in 2018. Therefore, middle-income economies are countries with a GNI per capita between US\$1,026 and US\$12,375 in 2018.

Annual macro panel data (Table 1) obtained from the World Bank include $\mathrm{CO}_{2}$ emissions (metric tonnes per capita), total human population, rural population, urban population, GDP (per capita GDP (US\$)), renewable energy consumption (\% of total final energy consumption), and forest area (squared kilometres). The World Bank dataset used for the study had already aggregated these variables for high-, low- and middle-income economies in the world, which were used for the study.

\subsection{Data Analysis}

Differences in population, $G D P$, renewable energy, and $\mathrm{CO}_{2}$ nexus in high- and low-income economies were estimated from panel data using the Granger causality Wald test, fixed-effects and random-effects regressions. The response variable is $\mathrm{CO}_{2}$ emissions and the explanatory variables are the total population, rural population, urban population, GDP, renewable energy consumption, and forest area (Table 1). Before these estima- tions, tests for cross-sectional dependence using the Pesaran cross-sectional dependence $(C D)$ test and unit roots test using the Levin-Lin-Chu unit root test were performed for the panel data.

\subsubsection{Fixed-Effects and Random-Effects Models}

Fixed-effects model assumes that errors in the variables could affect the outcome or predictor variables and should be controlled $[17,18]$. The model removes the effect of time-invariant characteristics to estimate the net impact of population, GDP, renewable energy consumption, and forest area on $\mathrm{CO}_{2}$ emissions. The model further assumes that the time-invariant characteristics are unique to a variable and should not be correlated with other variable characteristics $[19,20]$.

For random-effects model, the variation across economies (entities) is assumed to be random and uncorrelated with the explanatory variables $[18,21]$. The random-effects model assumes that the entity's error term is not correlated with the explanatory variables [18]. Following [18], the fixed-effects and random-effects models are presented in equations 1 and 2, respectively.

$$
\begin{gathered}
Y_{i t}=\beta_{0}+\beta_{1} X_{i t}+\beta_{2} X_{i t}+\alpha_{i t}+u_{i t}, \\
Y_{i t}=\beta_{0}+\beta_{1} X_{i t}+\beta_{2} X_{i t}+\alpha_{i t}+u_{i t}+\varepsilon_{i t},
\end{gathered}
$$

where: $Y_{i t}$ represents $\mathrm{CO}_{2}$ emissions (response variable); the subscript i represents high-, low- and middle-income economies (the panels or entities); the subscript $t$ represents years, 1960 to 2018 (time variable); $\beta_{0}$ denotes the intercept; $X_{i t}$ represents population, GDP, renewable energy consumption, and forest area (explanatory variables); $\beta$ represents coefficients for explanatory variables (parameters to be estimated); $\alpha_{i t}(i=1, \ldots, n)$ represents unknown intercept for each economy; $u_{i t}$ in equation 1 denotes the error term; $u_{i t}$ in equation 2 represents the between-entity error term; and $\varepsilon_{i t}$ represents the within-entity error term. Table 1 shows the variables used for the fixed-effects and random-effects estimates.

\section{Results and Discussion}

\section{1 $\mathrm{CO}_{2}$, Population, Renewable Energy, and GDP per Annum of High and Low-Income Economies from 1960-2018}

Mean $\mathrm{CO}_{2}$ emissions, population, renewable energy consumption, and GDP per annum of high-, low- and middle-income economies in the world for the period 1960-2018 are presented in Table 2. It shows that, on average, high-income economies across the globe emit 11.06 metric tonnes per capita $\mathrm{CO}_{2}$ annually in the past 58 years. Comparably, 
Definition of variables

\begin{tabular}{|l|l|}
\hline \multicolumn{1}{|c|}{ Variable } & \multicolumn{1}{c|}{ Definition } \\
\hline $\mathrm{CO}_{2}$ & $\begin{array}{l}\text { The natural logarithm of } \mathrm{CO}_{2} \text { emissions } \\
\text { (metric tonnes per capita) }\end{array}$ \\
\hline lnPopulation & $\begin{array}{l}\text { The natural logarithm of human } \\
\text { population }\end{array}$ \\
\hline $\begin{array}{l}\text { lnRural- } \\
\text { population }\end{array}$ & The natural logarithm of rural population \\
\hline $\begin{array}{l}\text { lnUrban- } \\
\text { population }\end{array}$ & $\begin{array}{l}\text { The natural logarithm of urban } \\
\text { population }\end{array}$ \\
\hline lnGDP & $\begin{array}{l}\text { The natural logarithm of GDP per capita } \\
\text { (current US\$) }\end{array}$ \\
\hline Renewable & $\begin{array}{l}\text { Renewable energy consumption (\% of } \\
\text { total final energy consumption) }\end{array}$ \\
\hline lnForest area & $\begin{array}{l}\text { The natural logarithm of forest area } \\
\text { (squared kilometres) }\end{array}$ \\
\hline
\end{tabular}

Source: World Bank [22].

low- and middle-income economies have respectively emitted only 0.34 and 2.24 metric tonnes per capita $\mathrm{CO}_{2}$ annually in the same period. All three types of economies in the world produced 13.64 metric tonnes per capita $\mathrm{CO}_{2}$ annually in the period 1960-2018, out of which high-income economies produced $81.09 \%$, while low and mid- dle-income economies, respectively, produced only $2.49 \%$ and $16.42 \%$. Thus, the lower the income level of a country, the lower the level of $\mathrm{CO}_{2}$ emissions, and vice versa. This could be attributed to high economic activities, industrialisation and urbanisation, which contribute immensely to $\mathrm{CO}_{2}$ emissions in high-income economies compared to low-income economies.

More than two-thirds (73.96\%) of the global population have lived in middle-income economies from 1960 to 2018; simultaneously, only $19.08 \%$ and $6.96 \%$, respectively, have lived in high- and low-income economies. In addition, an overwhelming majority of the world's rural (81.62 \%) and urban (64.56\%) population lived in middle-income economies in the period 19602018. Only $9.48 \%$ of the world's rural population lived in low-income economies from 1960 to 2018, which is more than that of high-income economies $(8.90 \%)$. Conversely, $31.56 \%$ of the world's urban population lived in high-income economies for the period, which is more than that of low-income economies (3.88 \%). Therefore, while low-income economies have a higher percentage of rural population, high-income economies have a higher percentage of urban population.

Table 2

$\mathrm{CO}_{2}$, population, renewable energy, and GDP per annum of high- and low- income economies (1960-2018)

\begin{tabular}{|c|c|c|c|c|c|c|c|c|}
\hline \multirow[b]{3}{*}{ Variable } & \multicolumn{5}{|c|}{ Mean per annum (1960-2018) } & \multicolumn{3}{|c|}{$\begin{array}{c}\text { Percentage share of } \\
\text { total }\end{array}$} \\
\hline & \multirow[b]{2}{*}{$\begin{array}{l}\text { High- } \\
\text { income } \\
\text { economies }\end{array}$} & \multirow[b]{2}{*}{$\begin{array}{l}\text { Low- } \\
\text { income } \\
\text { economies }\end{array}$} & \multirow[b]{2}{*}{$\begin{array}{c}\text { Middle- } \\
\text { income } \\
\text { economies }\end{array}$} & \multicolumn{2}{|c|}{ Pooled sample } & \multirow{2}{*}{ 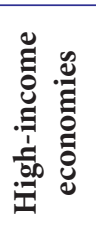 } & \multirow[b]{2}{*}{ 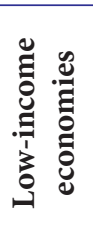 } & \multirow{2}{*}{ 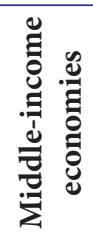 } \\
\hline & & & & Mean & Total & & & \\
\hline $\begin{array}{l}\mathrm{CO}_{2} \text { emissions (metric } \\
\text { tonnes per capita) }\end{array}$ & 11.06 & 0.34 & 2.24 & 4.54 & 13.64 & 81.09 & 2.49 & 16.42 \\
\hline $\begin{array}{l}\text { Population (number of } \\
\text { people) }\end{array}$ & 996130830 & 363215023 & 3860437164 & 1739927672 & 5219783017 & 19.08 & 6.96 & 73.96 \\
\hline $\begin{array}{l}\text { Rural population } \\
\text { (number of people) }\end{array}$ & 255519328 & 272125061 & 2344012379 & 957218923 & 2871656768 & 8.90 & 9.48 & 81.62 \\
\hline $\begin{array}{l}\text { Urban population } \\
\text { (number of people) }\end{array}$ & 740590962 & 91089962 & 1514832820 & 782171248 & 2346513744 & 31.56 & 3.88 & 64.56 \\
\hline $\begin{array}{l}\text { GDP [per capita } \\
\text { (US\$)] }\end{array}$ & 18909.80 & 455.62 & 1505.41 & 8178.68 & 20870.83 & 90.60 & 2.19 & 7.21 \\
\hline $\begin{array}{l}\text { Renewable energy } \\
\text { consumption (\% of } \\
\text { energy consumption) }\end{array}$ & 8.28 & 72.43 & 24.6509 & 35.12 & 105.3609 & 7.86 & 68.74 & 23.40 \\
\hline $\begin{array}{l}\text { Energy consumption } \\
\text { (kilogrammes of oil } \\
\text { equivalent per capita) }\end{array}$ & 4406.33 & - & 892.71 & 2830.13 & 5299.04 & 83.15 & - & 16.85 \\
\hline $\begin{array}{l}\text { Forest area (squared } \\
\text { kilometres) }\end{array}$ & 10073949 & 3660364 & 26415398 & 13272750 & 40149711 & 25.09 & 9.12 & 65.79 \\
\hline
\end{tabular}

* Energy consumption for low-income economies was missing in the World Bank data used for the study. Source: World Bank [22]. 
Average annual GDP per capita from 1960 to 2018 in high-income economies is US $\$ 18909.80$, which is, as expected, overwhelmingly higher than that of low (US\$455.62) and middle (US\$1505.41) income economies. Thus, on average, high-income economies have contributed $90 \%$ of the global GDP per capita for the past six decades, while low and middle-income economies have contributed only $10 \%$.

Table 2 demonstrates that, from 1960 to 2018 , only $8.28 \%$ of total energy consumption by high-income economies is from renewable sources. Conversely, the majority (72.43 \%) of energy consumed in low-income economies in the period 1960-2018 is renewable. Hence, low-income economies have contributed more than twothirds $(68.74 \%)$ of global renewable energy consumption in the past six decades compared to high-income economies who have contributed only $7.86 \%$. However, on average, high-income economies have consumed 4406.33 kilogrammes of oil equivalent per capita of energy annually in the past six decades, which is $83.15 \%$ of the world energy consumption.

Further, Table 2 shows the annual forest area of the three types of economies averaged from 1960 to 2018. Middle-income economies had 26415398 square kilometres from 1960 to 2018 per annum, which is approximately two-thirds $(65.79 \%)$ of the world's total forest area for the 58-year period, while high-income economies had 10073949 square kilometres (25.09\%) and low-income economies had 3660364 square kilometres (9.12\%).

\subsection{Trends of $\mathrm{CO}_{2}$, Population, Renewable Energy, and GDP in High and Low-Income Economies from 1960-2018}

Figure 1 compares the increase (decrease) trends in $\mathrm{CO}_{2}$ emissions, population, renewable energy, and GDP in the period 1960-2018 in high- (HIE), low- (LIE) and middleincome (MIE) economies. The figure shows that $\mathrm{CO}_{2}$ emissions rose steeply in high-income economies from 1960 to the 1970s, but were zigzagging from the late 1970 s to 2018 , showing a slight decline from the 2000 s to 2018. For low-income economies, $\mathrm{CO}_{2}$ emissions showed a zigzag trend from 1960 to the 1990 s, but then declined in the period from the 1990 s to 2018. For middle-income economies, $\mathrm{CO}_{2}$ emissions have continuously risen from 1960 to 2018; it was moderately steep in the period from the 1960 s to the 2000s, but increased rapidly from the 2000s to 2018. Thus, unlike in middle-income economies, $\mathrm{CO}_{2}$ emissions had shown a declining trend in high- and low-income economies in the past (ten) years.
Figure 1 further shows a continuous and sharp increase in total population in high-, low- and middle-income economies. However, there has been a continuous and sharp decline in rural population of high-income economies from 1960 to 2018 but a continuous and sharp rise for low and middle-income economies, though that of middle-income economies has been quite unchanged/flat since the 2000s. On the other hand, urban populations of high-, low- and middle-income economies have been continuously increasing in the period from 1960 to 2018. In addition, GDP had steeply risen in high-, low- and middle-income economies in the past six decades, though middle-income economies experienced a mild increase in GDP in the period 1960-2000. Renewable energy consumption had increased steeply in high- and low-income economies over the years, but decreased sharply in middle-income economies.

\subsection{Pesaran Cross-Sectional Dependence (CD) Test}

Cross-sectional dependence is a problem in panel data with long time series of more than twenty years [19]. Hence, in [23] CD test (appendix) was used to test for cross-sectional dependence in the dataset where the null hypothesis for the test of independence is that residuals across entities are uncorrelated. The test revealed that the probability is not significant, suggesting that there is no cross-sectional dependence in the macro panel dataset used for the study.

\subsection{Unit Root Test: Levin-Lin-Chu Unit Root Test}

It is important to perform the stationarity (panel unit root) test for panel data, especially when the time period is more than ten years and the number of observations is more than fifteen [24]. If values are non-stationary (if a unit root exists in the panel data), the estimated results may be misleading [24]. The Levin-Lin-Chu unit root test requires the ratio of the number of panels to time periods to be asymptotically zero. As a result, this method is appropriate for datasets with a small number of panels and relatively many time periods. The dataset used for this study comprises three panels (high-, lowand middle-income economies) and twenty-nine periods. Thus, the Levin-Lin-Chu [25] unit root test (Table 3) was used to test for the presence of a unit root in the panel dataset for $\mathrm{CO}_{2}$, population, GDP, and renewable energy consumption. The null hypothesis (Ho) in the Levin-LinChu unit root test states that panels contain unit roots, whereas the alternative hypothesis $(\mathrm{Ha})$ states that panels are stationary. 

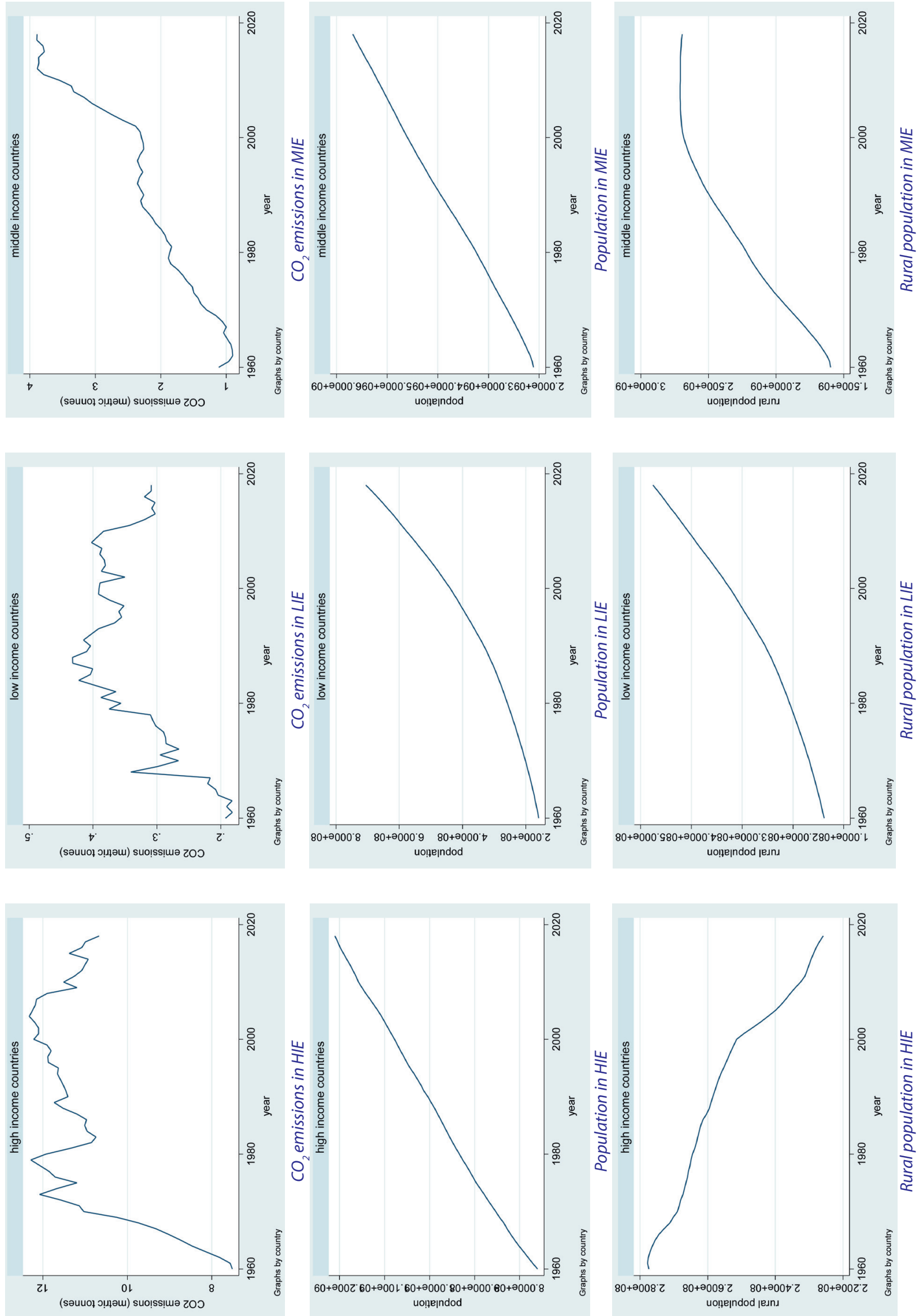

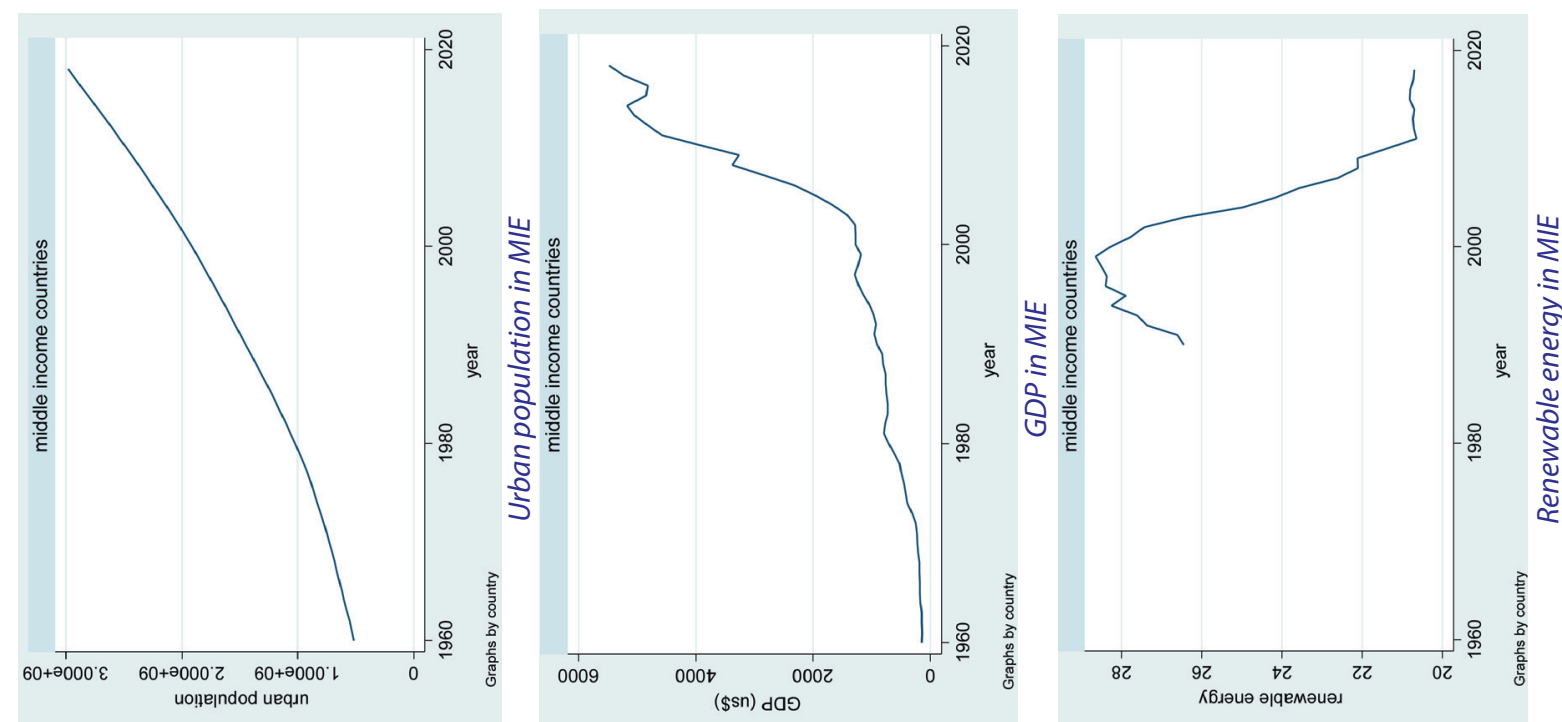

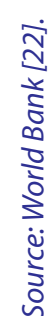
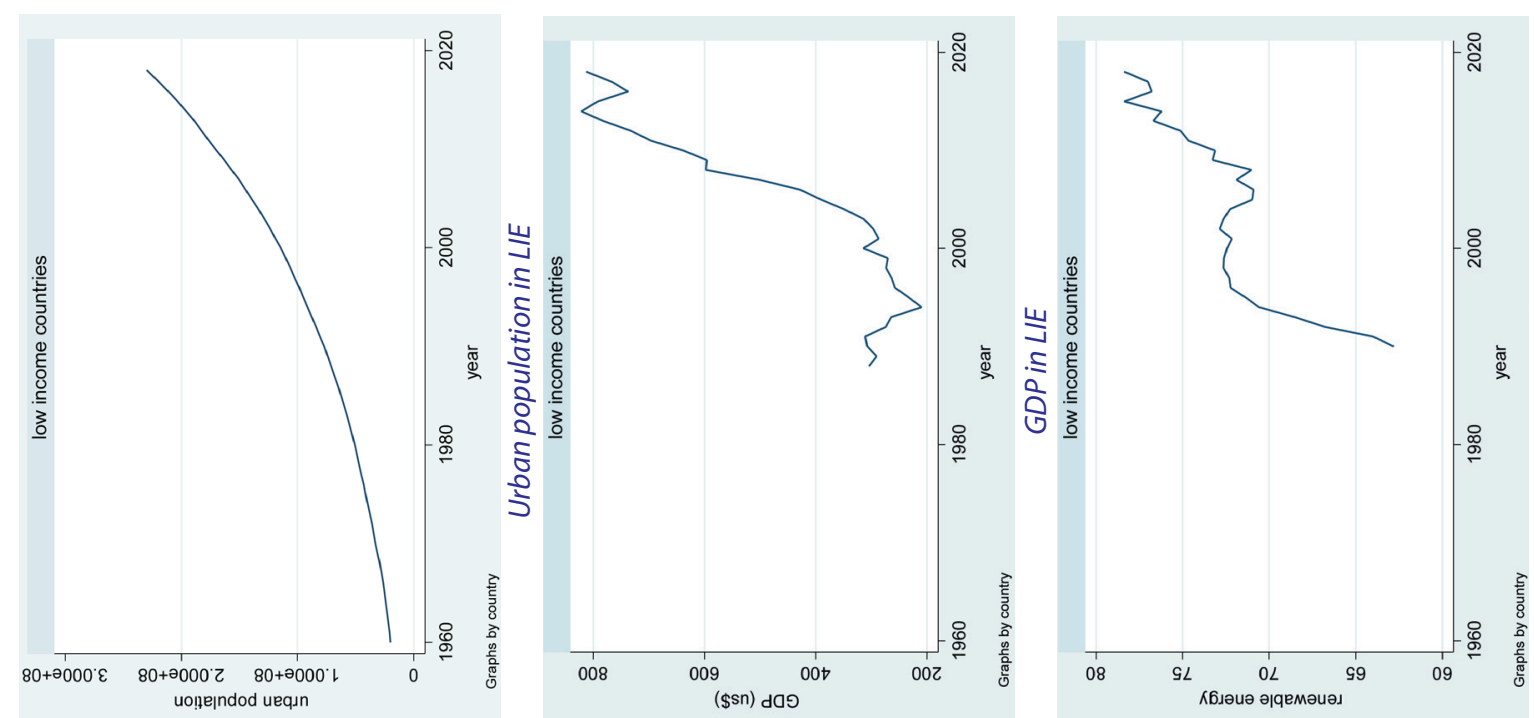

$\infty$
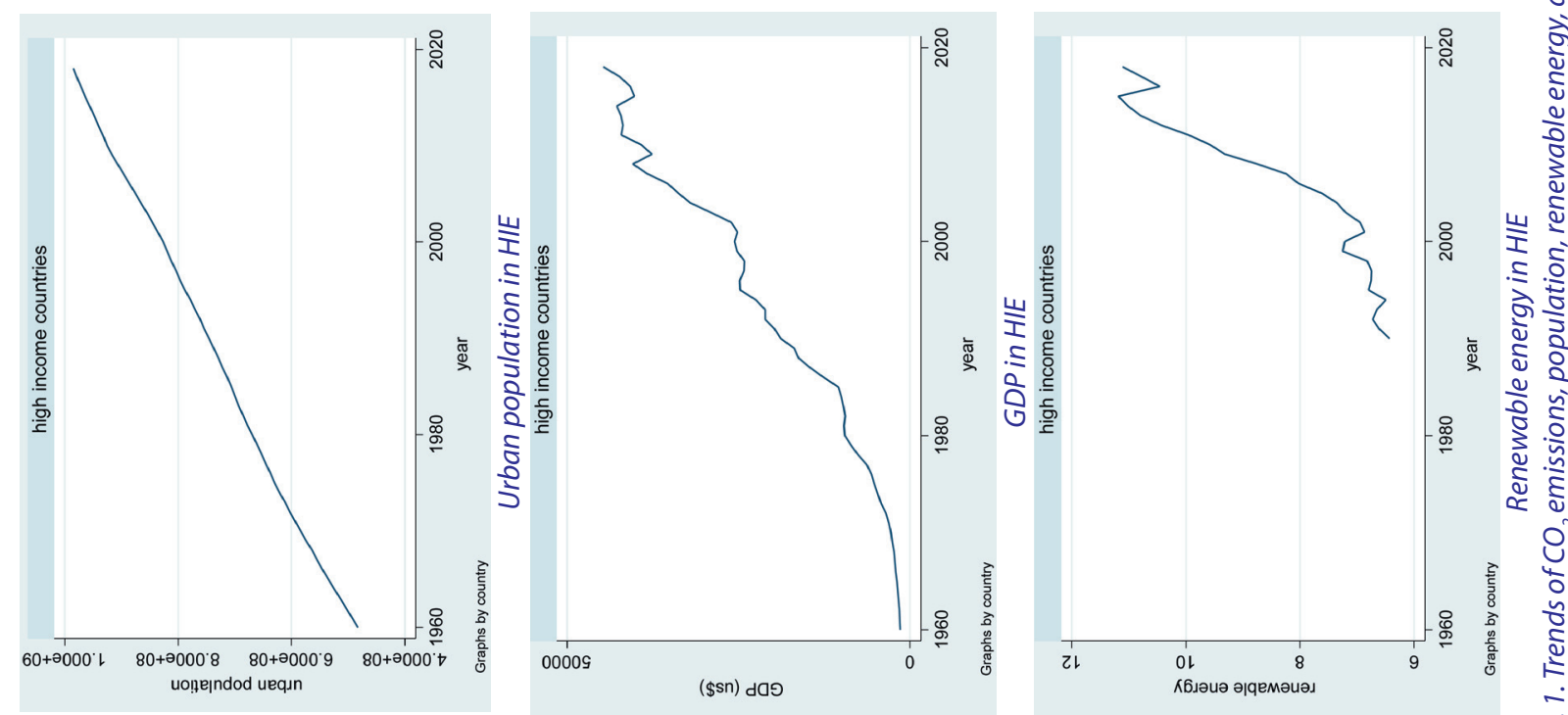

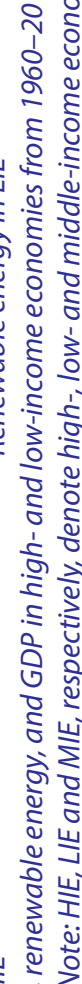


Levin-Lin-Chu unit-root tests

\begin{tabular}{|l|c|c|}
\hline \multirow{2}{*}{\multicolumn{1}{|c|}{ Variable }} & \multicolumn{2}{c|}{$\begin{array}{c}\text { Statictic for Levin-Lin-Chu } \\
\text { unit-root test }\end{array}$} \\
\cline { 2 - 3 } & $\begin{array}{c}\text { Unadjusted } \\
\text { t-test }\end{array}$ & Adjusted $\boldsymbol{t}$-test \\
\hline $\mathrm{CO}_{2}$ & -4.102 & $-1.575^{*}$ \\
\hline Population & -3.908 & $-3.358^{* * *}$ \\
\hline Rural population & -4.115 & $-3.808^{* * *}$ \\
\hline Urban population & -2.630 & $-1.610^{*}$ \\
\hline GDP & - & - \\
\hline $\begin{array}{l}\text { Renewable energy } \\
\text { consumption }\end{array}$ & -4.512 & $-1.800^{*}$ \\
\hline Number of panels & 3 & \\
\hline Number of periods & 29 & \\
\hline Asymptotics & $N / T->0$ & \\
\hline $\begin{array}{l}\text { Autoregressive }(A R) \\
\text { parameter }\end{array}$ & Common & \\
\hline
\end{tabular}

* The dataset for GDP was not strongly balanced. However, Levin-Lin-Chiu test requires strongly balanced data.

Source: World Bank [22].

The output in Table 3 shows that the LevinLin-Chu unit root test assumes a common autoregressive parameter for all three panels. As a result, it is unlikely that any of the parameters/panel variables $\left(\mathrm{CO}_{2}\right.$, population, rural population, urban population, or renewable energy) contain unit roots in either high-, low- or middle-income econ- omies while other economies do not. The tests for stationarity (panel unit root) in Table 3 indicate that the Levin-Lin-Chu bias-adjusted $t$ statistics are statistically significant for all five macro panel variables: $\mathrm{CO}_{2}$, population, rural population, urban population, and renewable energy consumption. Hence, the null hypothesis is rejected in favour of the alternative hypothesis. Therefore, it is concluded that the panel dataset used for the study is stationary (a unit root does not exist). This means that statistical properties of the various time series $\left(\mathrm{CO}_{2}\right.$, population, rural population, urban population, and renewable energy consumption) such as mean, variance, and autocorrelation are all constant over time.

\subsection{The Nexus between Population, GDP, Renewable Energy, and $\mathrm{CO}_{2}$ in High- and Low- Income Economies}

The main research question about the differences in the impacts of population, GDP and renewable energy consumption on $\mathrm{CO}_{2}$ emissions in high- and low-income economies, was answered using the Granger causality Wald test, fixed-effects and random-effects regressions.

\subsubsection{Granger Causality Wald Test}

The granger causality was used to test whether population, GDP, renewable energy consumption,

Table 4

Granger causality test of the nexus between population, GDP, renewable energy, forest area and $\mathrm{CO}_{2}$ emissions

\begin{tabular}{|c|c|c|c|c|}
\hline Equation & Excluded & Chi-squared & Degree of freedom & Probability of Chi-squared \\
\hline \multicolumn{5}{|c|}{ High-income economies } \\
\hline $\mathrm{CO}_{2}$ emissions & Population & 0.155 & 2 & 0.925 \\
\hline $\mathrm{CO}_{2}$ emissions & GDP & 8.409 & 2 & $0.008^{* * *}$ \\
\hline $\mathrm{CO}_{2}$ emissions & Renewable energy & 9.480 & 2 & $0.009^{* * *}$ \\
\hline $\mathrm{CO}_{2}$ emissions & Forest area & 22.861 & 1 & $0.000^{* * *}$ \\
\hline $\mathrm{CO}_{2}$ emissions & ALL & 862.250 & 7 & $0.000^{* * *}$ \\
\hline \multicolumn{5}{|c|}{ Low-income economies } \\
\hline $\mathrm{CO}_{2}$ emissions & Population & 1005.500 & 1 & $0.000^{* * *}$ \\
\hline $\mathrm{CO}_{2}$ emissions & $G D P$ & 11.461 & 2 & $0.003^{* * *}$ \\
\hline $\mathrm{CO}_{2}$ emissions & Renewable energy & 3.332 & 2 & 0.189 \\
\hline $\mathrm{CO}_{2}$ emissions & Forest area & 10.524 & 2 & $0.005^{* * *}$ \\
\hline $\mathrm{CO}_{2}$ emissions & ALL & 57501.000 & 7 & $0.000^{* * *}$ \\
\hline \multicolumn{5}{|c|}{ Middle-income economies } \\
\hline $\mathrm{CO}_{2}$ emissions & Population & 1110.900 & 1 & $0.000^{* * *}$ \\
\hline $\mathrm{CO}_{2}$ emissions & $G D P$ & 3.657 & 2 & 0.161 \\
\hline $\mathrm{CO}_{2}$ emissions & Renewable energy & 7.286 & 2 & $0.026^{* *}$ \\
\hline $\mathrm{CO}_{2}$ emissions & Forest area & 8.522 & 2 & $0.014^{* *}$ \\
\hline $\mathrm{CO}_{2}$ emissions & ALL & 13626.000 & 7 & $0.000^{* * *}$ \\
\hline
\end{tabular}

*** and ${ }^{* *}$ respectively indicate the $1 \%$ and $5 \%$ significance levels Source: World Bank [22]. 
and forest area are causally related to $\mathrm{CO}_{2}$ emissions in high-, low- and middle-income economies (Table 4). Table 4 indicates that for high-income economies, renewable energy consumption and forest area granger cause $\mathrm{CO}_{2}$ emissions. Growth in population in high-income economies is not causally related to $\mathrm{CO}_{2}$ emissions. For low-income economies, population, GDP, and forest area granger cause $\mathrm{CO}_{2}$ emissions. The consumption of renewable energy in low-income economies is causally unrelated to $\mathrm{CO}_{2}$ emissions. Similarly, population, renewable energy consumption, and forest granger cause $\mathrm{CO}_{2}$ emissions in middle-income economies. $\mathrm{CO}_{2}$ emissions in middle-income economies are not causally related to an increase in GDP.

The influences of population, renewable energy consumption and GDP on $\mathrm{CO}_{2}$ emissions in high-, low- and middle-income economies differ. For instance, in high-income economies, growth in population per se may not granger cause $\mathrm{CO}_{2}$ emissions. However, economic activities of the ever increasing population such as (renewable) energy consumption and forest conservation contribute to $\mathrm{CO}_{2}$ emissions. These economic activities boost $G D P$, which is correlated with $\mathrm{CO}_{2}$ emissions. However, 'ALL' in Table 3 suggests that all four panel variables jointly granger cause $\mathrm{CO}_{2}$ emissions in each panel (high-, low- and middle-income economies), likely because population, GDP, renewable energy consumption and forest areas are closely related. For instance, increase in human population of a country leads to the clearance of forest area for settlement and economic activities such as agricultural production and industrialisation, which in turn increase the country's GDP. In addition, an increase in human population leads to the consumption of more non-renewable energy compared to renewable energy.

\subsubsection{Empirical Results from Random-effects and Fixed-effects Regressions}

In addition to the Granger causality Wald test, we estimated fixed-effects and random-effects to examine differences in the impacts of population, GDP and renewable energy on $\mathrm{CO}_{2}$ emissions in high- and low-income economies (Table 5). The three panels - high, low and middle-income economies - served as the group variable for the fixed-effects and random-effects regressions. The $F$-test (in fixed-effects) and chi-squared (in random-effects) are statistically significant at $1 \%$, indicating that the models fit for the estimation. The adjusted $R$-squared implies that the predictor variables (population, $G D P$, and renewable energy) used in the fixed-effects and random-ef- fects regressions, respectively, contributed $92.5 \%$ and $99.9 \%$ of the variations in the outcome variable $\left(\mathrm{CO}_{2}\right.$ emissions). Corr $\left(u_{-} i, \mathrm{Xb}\right)$ in Table 5 implies that the errors $\left(u_{i}\right)$ are correlated with the regressors in the fixed-effects model, though they are not correlated in the random-effects regression. Sigma $u$ explains the standard deviation of residuals within groups, $\left(u_{i}\right)$ and sigma e explain the standard deviation of residuals that is the overall error term $\left(e_{i}\right)$. Rho (the fraction of variance as a result of $u_{-} i$ ) implies that $99.9 \%$ and $80 \%$ of the variance is due to differences across panels in the fixed-effects and random-effects regressions, respectively.

Table 5 reveals that population, rural population, urban population, $G D P$, renewable energy and forest area are related to $\mathrm{CO}_{2}$ emissions. The fixed-effects and random-effects regressions revealed that population directly correlates with $\mathrm{CO}_{2}$ emissions in high-, low- and middle-income economies. However, the coefficients suggest that the magnitudes of correlation vary. The fixed-effects estimates suggest that an increase in population by one person across time increases $\mathrm{CO}_{2}$ emissions by $22.078 \%, 70.354 \%$ and $26.567 \%$ respectively in high-, low- and middle-income economies, other factors being equal. This infers that even though there is a direct relationship in all three economies, the impact of population on $\mathrm{CO}_{2}$ emissions in low-income economies is greater than that of high-income economies. This could be attributed to technological advancement of high-income countries, which aid in reducing the impacts of population on $\mathrm{CO}_{2}$ emissions compared to low-income countries. Simon [26] asserted that population growth would lead to an increase in knowledge, resources and income subsequent development of technologies to control pollution. The fixed-effects estimates suggest that this theory is likely to work in high-income economies than low-income economies.

In addition to total population, Table 5 reveals that rural and urban populations have varying impacts on $\mathrm{CO}_{2}$ emissions. The fixed-effects and random-effects regressions revealed that while rural population growth has an indirect correlation with $\mathrm{CO}_{2}$ emissions in high-, low- and middle-income economies, urban population growth has a direct correlation. Therefore, as the proportion of a country's rural population increases, $\mathrm{CO}_{2}$ emissions decline. In contrast, as the proportion of a country's urban population increases, $\mathrm{CO}_{2}$ emissions rise. This could be attributed to industrialisation, building and construction, electrification, burning of fossil fuel (via automobiles), and other activities which are predominant among urban 
Table 5

Fixed-effects and random-effects regressions for examining the nexus between population, GDP, renewable energy, and $\mathrm{CO}_{2}$ in high- and low-income- economies

\begin{tabular}{|c|c|c|c|c|c|}
\hline \multirow[b]{2}{*}{$\begin{array}{l}\text { Explanatory } \\
\text { variable }\end{array}$} & \multicolumn{4}{|c|}{ Coefficient (standard error) for fixed-effects regression } & \multirow{2}{*}{$\begin{array}{c}\text { Coefficient } \\
\text { (standard error) } \\
\text { for random- } \\
\text { effects GLS } \\
\text { regression: } \\
\text { pooled sample }\end{array}$} \\
\hline & $\begin{array}{l}\text { High-income } \\
\text { economies }\end{array}$ & $\begin{array}{l}\text { Low-income } \\
\text { economies }\end{array}$ & $\begin{array}{l}\text { Middle-income } \\
\text { economies }\end{array}$ & Pooled sample & \\
\hline Population & $22.078(5.335)^{* * \star}$ & $70.354(27.604)^{* *}$ & $26.567(10.993)^{\star *}$ & $1.378(1.009)$ & $2.545(1.127)^{* *}$ \\
\hline Rural population & $-2.917(1.003)^{* * *}$ & $-35.956(11.905)^{* * *}$ & $-6.459(2.241)^{* * *}$ & $-1.906(0.328)^{* * *}$ & $-1.382(0.362)^{* * *}$ \\
\hline Urban population & $15.438(3.794)^{* * *}$ & $28.349(12.409)^{* *}$ & $13.277(5.443)^{* *}$ & $0.095(0.521)$ & $1.124(0.560)^{* *}$ \\
\hline GDP & $4.049(2.070)^{*}$ & $0.144(0.073)^{*}$ & $0.136(0.036)^{* * *}$ & $0.002(0.042)$ & $0.119(0.040)^{* * *}$ \\
\hline Renewable energy & $-0.208(0.079)^{* *}$ & $-2.592(0.496)^{* * *}$ & $-0.138(0.382)$ & $-0.888(0.120)^{* * *}$ & $-0.887(0.132)^{* * *}$ \\
\hline Forest area & $-12.543(5.699)^{* *}$ & $-0.855(1.323)$ & $-6.156(2.061)^{* * *}$ & $-1.721(0.799)^{\star *}$ & $-0.501(0.230)^{* *}$ \\
\hline Constant & $-114.090(63.788)^{\star}$ & $193.159(104.471)^{*}$ & $62.244(84.300)$ & $42.869(15.899)^{* * *}$ & $-8.187(1.222)^{* * *}$ \\
\hline $\begin{array}{l}\text { No. of } \\
\text { observations }\end{array}$ & 29 & 29 & 29 & 87 & 87 \\
\hline Group variable & Country & Country & Country & Country & Country \\
\hline Number of groups & 1 & 1 & 1 & 3 & 3 \\
\hline$F$ & 35.95 & 24.59 & 1141.03 & 132.78 & - \\
\hline Prob $>F$ & 0.000 & 0.000 & 0.000 & 0.000 & - \\
\hline Wald chi-squared & - & - & - & & 66614.12 \\
\hline Prob $>$ chi-squared & - & - & - & & 0.000 \\
\hline $\begin{array}{l}\text { Adjusted R2: } \\
\text { within }\end{array}$ & 0.9074 & 0.870 & 0.997 & 0.911 & 0.885 \\
\hline $\begin{array}{l}\text { Adjusted R2: } \\
\text { between }\end{array}$ & - & - & - & 0.058 & 1.000 \\
\hline $\begin{array}{l}\text { Adjusted R2: } \\
\text { overall }\end{array}$ & 0.9074 & 0.870 & 0.997 & 0.925 & 0.999 \\
\hline Corr (u_i, Xb) & - & - & - & -0.797 & 0 (assumed) \\
\hline Sigma_u & - & 一 & - & 2.815 & 0 \\
\hline Sigma_e & 0.014 & 0.041 & 0.014 & 0.045 & 0.045 \\
\hline Rho & - & - & - & 0.999 & 0.800 \\
\hline
\end{tabular}

Note: The outcome variable for the estimations is $\mathrm{CO}_{2}$ emissions. ${ }^{* *}$, ${ }^{\star *}$ and ${ }^{\star}$ respectively indicate the $1 \%, 5 \%$ and $10 \%$ significance levels.

Source: World Bank [22].

population. Similar to total population, the coefficients in Table 5 suggest that the impact of rural and urban population on $\mathrm{CO}_{2}$ emissions is bigger in low-income economies than high-income economies.

GDP is directly related to $\mathrm{CO}_{2}$ emissions in high-, low- and middle-income economies. The fixed-effects estimates indicate that as GDP increases by US $\$ 1$ across time, $\mathrm{CO}_{2}$ emissions increase by $4.049 \%$ in high-income economies and $0.144 \%$ in low-income economies, other factors being equal. Thus, the coefficients of the fixed-effects estimates suggest that the impact of GDP growth on $\mathrm{CO}_{2}$ emissions is greater in high-income economies than in low-income economies. To boost GDP of a country, economic activities are pertinent. However, economic activities are heavily related to $\mathrm{CO}_{2}$ emissions. High-income econo- mies are more likely to engage in several income generating activities than low-income economies. Industrial processes, energy consumption through electricity and heat, transportation, various forms of burning fossil fuels and other economic activities that boost GDP may be more prevalent in high-income economies than in low-income economies.

Renewable energy has an inverse relationship with $\mathrm{CO}_{2}$ emissions in high-, low- and middle-income economies. For the pooled estimates, the fixed-effects and random-effects estimates show that as the proportion of renewable energy in a country's total final energy consumption increases by $1 \%, \mathrm{CO}_{2}$ emissions decline by $0.888 \%$. The fixed-effects estimates suggest that as the proportion of renewable energy in total final energy consumption increases by $1 \%, \mathrm{CO}_{2}$ emis- 
sions decline by $0.208 \%$ and $2.592 \%$ in high- and low-income economies, respectively. Therefore, the impact of renewable energy consumption in reducing $\mathrm{CO}_{2}$ emissions in low-income economies is greater than that of high-income economies. Though not significant for low-income economies, Table 5 reveals that forest area is indirectly correlated with $\mathrm{CO}_{2}$ emissions. The pooled estimates reveal that as the forest area of a country increases by a squared kilometre, $\mathrm{CO}_{2}$ emissions decline by $1.721 \%$ (fixed-effects) or $0.501 \%$ (random-effects).

Results from the Granger causality Wald test, fixed-effects and random-effects regressions have clearly revealed that growth in population and GDP has a direct correlation with $\mathrm{CO}_{2}$ emissions in high-, low- and middle-income economies, while renewable energy consumption has an indirect correlation. There are many human causes of $\mathrm{CO}_{2}$ emissions [27, 28]. Growth in the human population of a country increases the demand for goods and services, which results in an increase in production activities. This increases economic activities like agricultural production, building and construction, establishment of factories, energy/electricity consumption, manufacturing and use of automobiles, and other production and manufacturing activities. The promotion of economic activities is known to increase GDP. However, they release $\mathrm{CO}_{2}$ through deforestation, cement production, burning of fossil fuels (such as natural gases, wood, oil, coal, and gasoline) for electricity, heat and transportation. This fact suggests that growth in GDP (through economic activities) increases $\mathrm{CO}_{2}$ emissions. In line with the above findings, Dong et al. [12] found that the population has a direct relationship with $\mathrm{CO}_{2}$ emissions. Dong et al. [12], Kang et al. [13], Liu \& Hao [14], Salman et al.[16] observed a positive relationship between $\mathrm{CO}_{2}$ emissions and GDP (economic growth).

Investments in renewable energy sources such as hydropower, wind, solar, geothermal and biomass would certainly reduce $\mathrm{CO}_{2}$ emissions in a country. The negative impact of renewable energy consumption on $\mathrm{CO}_{2}$ emissions is consistent with findings of Inglesi-lotz and Dogan [1], Zoundi [8], Hoon et al. [10], Dong et al. [12], Kang et al. [13], Nathaniel \& Iheonu [15], Salman et al. [16].

We revealed that forest area size has an indirect impact on $\mathrm{CO}_{2}$ emissions. Growing forest plants absorb and reduce $\mathrm{CO}_{2}$. However, growth in a country's population and economic activities in most cases leads to land clearing and deforestation. These reduce the country's forest area, which subsequently reduces the absorption of atmos- pheric $\mathrm{CO}_{2}$. Thus, there is the likelihood that $\mathrm{CO}_{2}$ is emitted more than the earth's flora could absorb.

\section{Conclusions and Recommendations}

This paper has established that the lower the income of a country, the lower the level of $\mathrm{CO}_{2}$ emissions, and vice versa. Thus, high-income economies emit more $\mathrm{CO}_{2}$ than low-income economies. For high-income economies, renewable energy consumption and forest area granger cause $\mathrm{CO}_{2}$ emissions. Simultaneously, growth in population is not causally related to $\mathrm{CO}_{2}$ emissions. For low-income economies, population, GDP and forest area granger cause $\mathrm{CO}_{2}$ emissions, while renewable energy is causally unrelated to $\mathrm{CO}_{2}$ emissions. The fixed-effects and random-effects regressions revealed that population and GDP directly correlate with $\mathrm{CO}_{2}$ emissions in high-, low- and middle-income economies, though the coefficients suggest that the magnitudes of correlation vary. Additionally, the coefficients indicate that the impact of population on $\mathrm{CO}_{2}$ emissions in low-income economies is greater than that of high-income economies. While rural population growth has an indirect correlation with $\mathrm{CO}_{2}$ emissions in high-, low- and middle-income economies, urban population growth has a direct correlation. The impact of GDP growth on $\mathrm{CO}_{2}$ emissions is greater in high-income economies than in low-income economies. Renewable energy has an inverse relationship with $\mathrm{CO}_{2}$ emissions in high-, low- and middle-income economies. The impact of renewable energy consumption in reducing $\mathrm{CO}_{2}$ emissions in low-income economies is greater than in high-income economies. Therefore, this paper has shown that though the direction of correlation is the same, there are differences in the magnitude of impacts of population, GDP, and renewable energy consumption on $\mathrm{CO}_{2}$ emissions in high- and low-income economies.

The research findings have significant policy implications. To reduce $\mathrm{CO}_{2}$ emissions, policy makers should develop effective policies to enhance renewable energy consumption to meet the ever increasing demand for energy by the growing population. However, it is essential to consider issues surrounding the environmental harm and the cost of renewable energy utilisation, which is comparable to the threat of $\mathrm{CO}_{2}$ emissions.

As such, countries should endeavour to create appropriate technologies and strategies to enhance their safe utilisation. Government should promote low carbon emissions economic activities. Given that $\mathrm{CO}_{2}$ emissions increase with growth in population, GDP and reduction in renewable energy consumption across economies, 
international cooperation is necessary to reduce global $\mathrm{CO}_{2}$ emissions. Thus, both low- and high-income economies should adopt measures to minimise non-renewable energy consumption. For instance, governments should impose taxes on all fuel-related activities to reduce $\mathrm{CO}_{2}$ emissions. Most economic activities that boost GDP of countries often lead to a rise in energy consumption and increase in $\mathrm{CO}_{2}$ emissions. Therefore, to reduce $\mathrm{CO}_{2}$ emissions, the process of economic growth should be accompanied by the transition to renewables. Population growth should be managed at the global level since it greatly contributes to $\mathrm{CO}_{2}$ emissions. Forest conservation is crucial in minimising $\mathrm{CO}_{2}$ emissions. Thus, policy makers should create and develop policies that prevent cutting down of trees and enhance afforestation. Governments should provide incentives to involve people in afforestation and forest conservation.

\section{References}

1. Inglesi-Lotz, R. and Dogan, E. (2018). The role of renewable versus non-renewable energy to the level of $\mathrm{CO}_{2} \mathrm{emis}^{-}$ sions a panel analysis of sub- Saharan Africa’s Big 10 electricity generators. Renew. Energy, Vol. 123 (C), 36-43.

2. Mohmmed, A., Li, Z., Olushola, A. and Su, H. (2019). Resources, conservation and recycling driving factors of $\mathrm{CO}_{2}$ emissions and nexus with economic growth, development and human health in the top ten emitting countries. Resour. Conserv. Recycl, 148, 157-169.

3. Zhou, C. and Wang, S. (2018). Examining the determinants and the spatial nexus of city-level $\mathrm{CO}_{2}$ emissions in China: a dynamic spatial panel analysis of China's cities. J. Clean. Prod 171: 917-926.

4. Wen, L. and Shao, H. (2019). Science of the total environment analysis of in fl uencing factors of the $\mathrm{CO}_{2}$ emissions in China: Nonpara-metric additive regression approach. Sci Total Environ, 694, 133-144.

5. Can, H. and Ozge, K (2019). The relationship between renewable energy consumption and economic growth: the case of Bulgaria. Int J Energy Ssctor Management 13(3): 573-589.

6. Marina, M., Dinu, M., Socol, A. and Socol, C. (2018). Renewable energy consumption and economic growth: causality relationship in Central and Eastern European countries. PLoS ONE. pp. 1-29. https://doi.org/10.1371/journal. pone.0202951.

7. Akadri, S. S., Benkum, V. F. and Sarkodie, S. A. (2019). Contemporaneous interaction between energy consumption , economic growth and environmental sustainability in South Africa: what drives what? Sci Total Environ, 686, 468-475. https://doi.org/10.1016/j.scitotenv.2019.05.421.

8. Kang, S.H., Islam, F. and Tiwari, A.K. (2019). The dynamic relationships among $\mathrm{CO}_{2}$ emissions, renewable and non-renewable energy sources, and economic growth in India: evidence from time-varying Bayesian VAR model. Struct Chang Econ Dyn, 50, 90-101. https://doi.org/10.1016/j.strueco.2019.05.006.

9. Wang, Q. and Zhou, Y. (2019). Imbalance of carbon emissions embodied in the US-Japan trade: temporal change and driving factors. J Clean Prod, 237. https://doi.org/10.1016/j.jclepro.2019.117780.

10. Dong, K., Hochman, G., Zhang, Y., Sun, R., Li, H. and Liao, H. (2018). CO emissions, economic and population growth, and renewable energy: empirical evidence across regions. Energy Econ, 75, 180-192. https://doi.org/10.1016/j. eneco.2018.08.017.

11. Mardani, A., Streimikiene, D., Cavallaro, F., Loganathan, N. and Khoshnoudi, M. (2018). Science of the total environment carbon dioxide $\left(\mathrm{CO}_{2}\right)$ emissions and economic growth: a systematic review of two decades of research from 1995 to 2017. Sci Total Environ, 649, 31-49. https://doi.org/10.1016/j.scitotenv.2018.08.229.

12. Zoundi, Z. (2016). $\mathrm{CO}_{2}$ emissions, renewable energy and the Environmental Kuznets Curve: a panel cointegration approach. Renew Sustain Energy Rev 72: 1067-1075. http://dx.doi.org/10.1016/j.rser.2016.10.018.

13. Kang, S. H., Islam, F. and Tiwari, A. K. (2019). The dynamic relationships among $\mathrm{CO}_{2}$ emissions, renewable and non-renewable energy sources, and economic growth in India: evidence from time-varying Bayesian VAR model. Struct Chang Econ Dyn, 50, 90-101. https://doi.org/10.1016/j.strueco.2019.05.006.

14. Liu, Y. and Hao, Y. (2018). The dynamic links between $\mathrm{CO}_{2}$ emissions, energy consumption and economic development in the countries along the belt and road. Sci Total Environ, 645, 674-683. https://doi.org/10.1016/j.scitotenv.2018.07.062.

15. Nathaniel, S.P. and Iheonu, C.O. (2019). Carbon dioxide abatement in Africa: the role of renewable and non-renewable energy consumption. Sci Total Environ, 679, 337-345. https://doi.org/10.1016/j.scitotenv.2019.05.011.

16. Salman, M., Long, X., Dauda, L. and Mensah, C.N. (2019). The impact of institutional quality on economic growth and carbon emissions: evidence from Indonesia, South Korea and Thailand. J. Clean. Prod, 241, 118331. https://doi. org/10.1016/j.jclepro.2019.118331

17. Baum, C. F. (2016). An introduction to modern econometrics using Stata. USA: Stata Press. 341 p.

18. Torres-Reyna, O. (2007). Panel data analysis: fixed and random effects using Stata (v. 4.2). Princeton University, Data and Statistical Services. $40 \mathrm{p}$.

19. Baltagi, B. H. (2008). Econometric analysis of panel data, fourth edition. USA: Wiley and Sons. 366 p.

20. Gelman, A. and Hill, J. (2007). Data analysis using regression and multilevel/hierarchical models. Cambridge, New York, Cambridge University Press. 624 p. 
21. Stock, J. H. (2007). Watson MW. Introduction to econometrics, second edition. Boston, Pearson Addison, Wesley. $769 \mathrm{p}$.

22. World Bank (2019). https://data.worldbank.org/indicator/NY.GDP.MKTP.KD? locations= 1 W\&view=chart. (Accessed on 15/10/2019).

23. Pesaran, M. H. (2004). General diagnostic tests for cross section dependence in panels. University of Cambridge, Faculty of Economics, United Kingdom. Cambridge Working Papers in Economics, Number 0435.

24. Hadri, K. (2000). Testing for stationarity in heterogeneous panel data. Econ J, 3(2), 148-161.

25. Levin, A., Lin, C. F. and Chu, C. S. J. (2002). Unit root tests in panel data: asymptotic and finite-sample properties. J Econ, 108(2), 1-24.

26. Simon, J. L. (1977). The economics of population growth. New Jersey, USA: Princeton University Press. 592 p.

27. Begum, R. A., Sohag, K., Abdullah, S. M. S., and Jaafar, M. (2015). $\mathrm{CO}_{2}$ emissions, energy consumption, economic and population growth in Malaysia. Renew Sustain Energy Rev, 41(2), 594-601.

28. Gill, A. R., Kuperan, K. V. and Hassan, S.A. (2018). Test of environmental Kuznets curve for carbon emission and potential of renewable energy to reduce greenhouse gases in Malaysia. Env Dev Sust 20(2): 1103-1114.

\section{About the authors}

Ernest Baba Ali - Department of Environmental Economics, Ural Federal University; http://orcid.org/0000-00017053-3492 (19, Mira St., Ekaterinburg, 620002, Russian Federation; e-mail: ernestali2014@gmail.com).

Bismark Amfo - Department of Agricultural Economics, Agribusiness and Extension, University of Energy and Natural Resources; https://orcid.org/0000-0002-5009-2033 (Post Office Box 214, Sunyani, Ghana, West Africa).

\section{Информация об авторах}

Эрнест Баба Али - кафедра экономики природопользования, Уральский федеральный университет; http:// orcid.org/0000-0001-7053-3492 (Российская Федерация, 620002, Екатеринбург, ул. Мира 19; e-mail: ernestali2014@ gmail.com).

Бисмарк Амфо - департамент экономики сельского хозяйства и агробизнеса, Университет энергетики и природных ресурсов; https://orcid.org/0000-0002-5009-2033 (Гана, Ашанти, г. Кумаси).

Дата поступления рукописи: 27.05.2020.

Прошла рецензирование: 28.07.2020.

Принято решение о публикации: 18.12.2020.

Received: 27 May 2020

Reviewed: 28 July 2020

Accepted: 18 Dec 2020 